\title{
Ds C Spoelstra en die Nederduitsch Hervormde Kerk
}

\author{
C J du Bruin \& S J Botha \\ Departement Kerkgeskiedenis (Afd A) \\ Universiteit van Pretoria
}

\begin{abstract}
Rev C Spoelstra and the Nederduitsch Hervormde Kerk

The inter relationship between 'Rev $C$ Spoelstra and the Nederduitsch Hervormde Kerk' is studies from three different perspectives: Spoelstra with or as part of the church (a positive relationship). Secondly, there is the increasing tension between Spoelstra and Rev M J Goddefroy (Goddefroy eventually became to Spoelstra the representation of the whole Nederduitsch Hervormde Kerk). Thirdly, Spoelstra opposed the whole Nederduitsch Hervormde Kerk and not only Goddefroy.
\end{abstract}

\section{INLEIDING}

Die Nederduitsch Hervormde Kerk Gemeente Pretoria vier vanjaar (1995) sy 140e bestaansjaar. So ' $n$ feesjaar bied die geleentheid om die vroeëre predikante van die gemeente in herinnering te roep. Dit is egter opvallend dat daar aan een predikant, Ds C Spoelstra, byna nooit aandag geskenk word nie. In sommige vorige feespublikasies en selfs in 'n reeks artikels oor die vroeëre predikante van die gemeente in Die Wagter, 'n gemeenteblad uit die dertigerjare, word Spoelstra of heeltemal weggelaat of word daar net kortliks na hom verwys (Engelbrecht 1942; Pont 1980 \& Pont, Botha \& Storm 1986). Engelbrecht $(1953,1955)$ en Botha (1981) maak wel melding van Spoelstra, maar dan wil hulle nie primêr na Spoelstra en sy verhouding met die Nederduitsch Hervormde Kerk vra nie. Dit kan as 'n leemte beskou word dat daar so min oor Spoelstra en sy verhouding met die Nederduitsch Hervormde Kerk in die verlede gereflekteer is. Hierdie artikel is 'n poging om in dié leemte te voorsien.

* Hierdie artikel is 'n verwerking van die resultate van die BD-skripsie, ingedien en aanvaar as deel van die vereistes vir die BD-graad (1996), Departement Kerkgeskiedenis, Fakulteit Teologie (Afd A), Universiteit van Pretoria, onder leiding van prof dr S J Botha. 
Die titel van die artikel Ds C Spoelstra en die Nederduitsch Hervormde Kerk kan op verskilllende maniere ingekleur word. In die eerste plek kan dit dui op 'n aanvanklike positiewe verhouding tussen Spoelstra en die betrokke kerk, dit wil sê Spoelstra saam met of deel van die Nederduitsch Hervormde Kerk. In die tweede plek dui dit op toenemende spanning tussen Spoelstra en ds M J Goddefroy. Goddefroy blyk later vir Spoelstra 'n versinnebeelding van die hele Nederduitsch Hervormde Kerk te word, en dit gee in die derde plek daartoe aanleiding dat Spoelstra teenoor die Nederduitsch Hervormde Kerk in geheel te staan kom - en nie net meer teenoor Goddefroy nie.

Vervolgens gaan daar in hierdie artikel ondersoek ingestel word na bogenoemde dimensies van die verhouding tussen Spoelstra en die Nederduitsch Hervormde Kerk. Ter aanvang word daar gepoog om die vraag 'Wie was Ds C Spoelstra?' met enkele biografiese besonderhede te beantwoord. In die daaropvolgende hoofstuk word daar gekyk na hoe Spoelstra predikant in die Nederduitsch Hervormde Kerk geword het. In hoofstuk vier val die fokus op die botsing tussen Spoelstra en Goddefroy. Die gevolge van die botsing - mettertyd ontaard dit in ' $n$. aanval geloods deur Spoelstra teen die hele Nederduitsch Hervormde Kerk - word in die voorlaaste hoofstuk belig. Ten slotte sal onder andere oorweeg moet word of die oorsaak van die botsing bo alle twyfel vasgestel kan word en of die impak van die botsing op die verdere verloop van Spoelstra se lewe en op sy verhouding met die Nederduitsch Hervormde Kerk ooit ten volle verdiskonteer sal kan word.

\section{WIE WAS DS C SPOELSTRA?}

In hierdie hoofstuk word enkele biografiese gegewens van Spoelstra aan die orde gestel. Die doel hiervan is om ' $n$ oorsigtelike beeld van sy lewe en werk te vorm, sodat sake rakende sy verhouding met die Nederduitsch Hervormde Kerk, wat later in die artikel uitgebou word, in perspektief ten opsigte van sy hele lewe gesien kan word.

Comelis Spoelstra is op 20 September 1860 te Sneek in die provinsie Friesland in Nederland gebore (Smit 1981:631). Hy ontvang sy voorbereidende opleiding met die oog op teologiese studie in Doetinchem. Sy teologiese studies voltooi hy aan die Universiteit van Leiden. Nadat hy deur die Klassikale Bestuur van Suid-Holland tot die evangeliebediening toegelaat is, word hy in Julie 1894 deur een van sy dosente, prof J H Gunning (jr), as leraar van die Nederlandse Hervormde Kerk in die gemeente Zoeterwoude bevestig.

In 1896 aanvaar Spoelstra 'n beroep na die gekombineerde Gemeentes Pretoria, Middelburg en Standerton van die Nederduitsch Hervormde Kerk in die Zuid-Afrikaansche Republiek met Pretoria as standplaas. Hy is op 31 Mei 1896 deur die ander predikant van die gekombineerde gemeentes, ds M J Goddefroy, as leraar bevestig. 
Deur sy opvlieënde geaardheid en eienaardige persoonlikheid het hy heel spoedig met Goddefroy en die kerkraad van Gemeente Pretoria gebots, en na vele onaangenaamhede kondig hy op 19 September 1897 heel onverwags van die kansel af aan dat hy op 1 Oktober sy ontslag neem.

Die botsing wat in Augustus 1897 begin het, het 'n onaangename strydepisode geword wat amptelik van die Nederduitsch Hervormde Kerk se kant beëindig is met die Algemene Kerkvergadering van 1898. Spoelstra het dit nie as die einde van die saak gesien nie. Vir hom sou die saak so te sê tot aan die einde van sy lewe duur.

Nadat Spoelstra in Pretoria reeds ' $n$ lewendige belangstelling in die kerklike verlede van die Zuid-Afrikaansche Republiek sowel as dié van Suid-Afrika in die algemeen getoon het, het hy hom in Kaapstad gaan vestig om hom daar op navorsing toe te lê. Sy navorsing was veral gemik op die skryf van 'n populêr-wetenskaplike handboek oor die geskiedenis van die Nederduitsch Gereformeerde Kerk (daarby word die Nederduitsch Hervormde of Gereformeerde Kerk ingesluit). Hy wend hom nou tot die Nederduitsch Gereformeerde Kerk omdat hy verbitter is teenoor die Nederduitsch Hervormde Kerk. Daar sal later aangetoon word hoe hy die Nederduitsch Hervormde Kerk in sy boeke aanval en ten koste van dié Kerk kant kies vir die Nederduitsch Gereformeerde Kerk.

In Mei 1898 het hy 'n opdrag van die Hollandsch-Afrikaansche Uitgevers-Maatschappij (HAUM) in verband met sy voorgenome kerkgeskiedenishandboek gekry. In die uitvoering van sy taak het hy die steun van die staatsargivaris, H C V Leibbrandt, en die aanmoediging van die Nederduitsch Gereformeerde Kerk (in die Kaapkolonie) se teologiese professore van Stellenbosch geniet. Aan die einde van 1898 was hy terug in Nederland om sy navorsing in die argiewe in Den Haag, Leiden en Amsterdam voort te sit. Die uitbreek van die Tweede Anglo-Boereoorlog (1899-1902) het Spoelstra verhinder om na Suid-Afrika terug te keer. Daarop moes hy andermaal in diens van die Hervormde Kerk in Nederland tree en het hy leraar geword van Heinoo by Zwolle in Overijsel. Hy was werksaam in die ge-meente vanaf 17 Desember 1899 tot 3 Januarie 1904.

Intussen het dit vir hom duidelik geword dat hy die boustowwe of bronne vir sy voorgenome geskiedenis van die Nederduitsch Gereformeerde Kerk behoort te versamel en uit te gee voordat hy die werk self opstel, aangesien die gebrek aan bronne die wetenskaplike beoefening van die kerkgeskiedskrywing belemmer het. Die oorspronklike, onuitgegewe stukke waarvan hy geweet het, moes dus onder sy toesig afgeskryf word. Voorts moes alle stukke wat op dié bronne kon lig werp, opgespoor word. Om hom hiermee te help, het die hoofbestuur van die Nederlandsch-Zuid-Afrikaansche Vereeniging in 1902 'n duisend gulden beskikbaar gestel.

Toe die Kaapse Sinode van die Nederduitsch Gereformeerde Kerk verder in 1903 $£ 400$ vir die voortsetting van die groot werk bewillig, het hy en sy vrou (voor hulle 
huwelik het sy as A Hunningher bekend gestaan) met hul twee kinders (hul oudste seuntjie Cornelis Abraham is op 12 Junie 1896 kort na hul eerste aankoms in Pretoria oorlede) in April 1904 weer na Suid-Afrika gekom, veral met die oog op die voortsetting van sy navorsingswerk. Op 25 Mei 1904 is hy na colloquium doctum ('n ondervraging in die plek van 'n proponentseksamen) as predikant van die Nederduitsch Gereformeerde Kerk in die Kaap toegelaat. In hierdie tyd orden hy die argiefstukke van die gemeentes wat in die tyd van die VOC en die eerste Britse bewind ontstaan het. Hy verrig terselfdertyd ook hulpdiens in die Gemeente Wynberg.

Nadat die Kaaplandse Nederduitsch Gereformeerde Kerk 'n verdere $£ 200$ vir die werk bewillig het, is Spoelstra laat 1905 weer na Nederland waar sy Bouwstoffen voor de geschiedenis der Nederduitsch-Gereformeerde Kerken in Zuid-Afrika in 1906 en 1907 in twee lywige dele deur die HAUM in Amsterdam uitgegee is.

Vir 'n derde keer kom Spoelstra in 1911 na Suid-Afrika met die gedagte om hom nou hier te vestig. Op 5 April 1911 word hy weer eens na colloquium doctum in die Nederduitsch Gereformeerde Kerk gelegitimeer. Hy het in die Gemeentes SomersetStrand, Potchefstroom en Franschhoek waargeneem, totdat hy weens swak gesondheid vroeg in 1913 na Nederland teruggekeer het. In 1917 verskyn sy laaste pennevrug: Het Kerkelijk en Godsdienstig leven der Boeren na den Grooten Trek: Historisch Kritisch Onderzocht by die uitgewer J H Kok in Kampen. In hoofstuk vyf van hierdie skripsie word daar na Spoelstra se houding teenoor die Nederduitsch Hervormde Kerk in die boek gekyk. Spoelstra is corlede voordat hy die derde deel van die Bouwstoffen en sy handboek vir die Suid-Afrikaanse kerkgeskiedenis kon voltooi, maar talle aantekeningboeke in die Kaapse Nederduitsch Gereformeerde Kerkargief getuig van sy uitgebreide navorsing in dié verband. Cornelis Spoelstra is op 12 Oktober 1918 op 58jarige ouderdom in 'n senu-inrigting in Ermelo-Veldwyk in die provinsie Gelderland in Nederland oorlede (Smit 1981: 631).

\section{DS C SPOELSTRA WORD PREDIKANT IN DIE NEDERDUITSCH HER- VORMDE KERK}

In Nederland is daar in sekere kringe van die Nederlandse Hervormde Kerk met belangstelling gekyk na die Nederduitsch Hervormde Kerk in die ZAR. Onder leiding van een van die belangstellendes, dr F van Gheel Gildemeester, predikant van die Nederlandse Hervormde Gemeente Den Haag, is 'n kommissie gevorm vir hulp aan die kerk in die ZAR.

Gedurende die tweede helfte van 1895 het ds M J Goddefroy 'n brief na Nederland geskryf waarin hy finansiële steun gevra het om 'n tweede predikant vir Pretoria te kan 
beroep (Botha 1981:136). Goddefroy se pleitrede in die brief is deur verskeie gesiene en invloedryke figure in die Nederlandse Hervormde Kerk ondersteun en het 'n gunstige gevolg gehad. Die Commissie van Advies voor het uitzenden van Ned Herv (d i die Nederlandse Hervormde Kerk) Predikanten naar Transvaal kon die dienste van Ds Cornelis Spoelstra van Zoeterwoude bekom. Die kommissie het nie alleen sy reiskoste verskaf nie, maar het ook onderneem om vir twee jaar lank sy traktement te betaal. Dit was egter volgens Botha (1981:136), 'n ongelukkige keuse want daarmee het twee predikante waarvan die karakters sodanig was dat hulle noodwendig sou bots, in dieselfde gemeente te staan gekom.

In die beroepsbrief is die woorde tot hulp van den tegenwoordigen staanden leeraar (Nederduitsch Hervormde Kerk kombinasie-gemeente Pretoria-MiddelburgStanderton $1897=$ NHK kombinasie-gemeente 1897) ingevoeg. Engelbrecht (1953: 353) voer as redes vir die invoeging aan dat die beroep net vir twee jaar was en dat Goddefroy reeds die staande of vaste predikant van die gekombineerde Gemeentes Pretoria, Middelburg en Standerton was. Hierdie ingevoegde woorde sou later een van die strydpunte in die Spoelstra-Goddefroy-botsing wees, aangesien dit groot ongelukkigheid by Spoelstra veroorsaak het. Spoelstra het die beroepsbrief egter so met die ingevoegde woorde en al aanvaar en die beroep aangeneem. Daarmee het hy hom verbind om twee jaar in die Gemeente Pretoria te bly, waar hy op 31 Mei 1896 deur Goddefroy bevestig is. Na die twee jaar sou hy vry wees om 'n beroep na enige ander gemeente in die Nederduitsch Hervormde Kerk in die ZAR aan te neem.

\section{DIE BOTSING TUSSEN SPOELSTRA EN GODDEFROY}

\subsection{Die oorsaak van die botsing?}

In Augustus 1897 het die botsing begin. Goddefroy het 'n bedrag van $\mathfrak{f 1 0}(=\mathrm{R} 20)$, wat Spoelstra by hom geleen het, teruggevra. Hieroor het Spoelstra hom blykbaar vererg. By die terugsending van die geld het hy aan Goddefroy 'n brief gerig waarin hy beweer het dat hy veronreg is wat finansiële sake betref en het hy selfs gesuggereer dat hy hof toe sou gaan.

In die brief, gedateer 25 Augustus 1897, het Spoelstra onder andere gesê: 'Indien de beurt te Johannesburg is in het "Rondgaand Hof" zal ik er DV heengaan. Ik heb mij evenwel voorgenomen dit jaar geen enkele beurt waar te nemen aan de ZASM lyn noch in de conculentsgemeente, tenzij gij my uitbetaald het mij wettig toekomende deel...' (Nederduitsch Hervormde Kerk 1898 = NHK 1898). Verder het hy ook nog die helfte van die inkomste van die sogenaamde 'Weduwenbeurs' geëis. Hierdie eise van Spoelstra het egter geen gronde gehad nie, aangesien die kommissie met wie se hulp hy uit Nederland gekom het, hom ten volle vergoed het (Botha 1981:170). 
Goddefroy, wat Spoelstra se reaksie as beledigend en belasterend beskou het, het nie op hom laat wag nie en het net so skerp teruggeskryf op 8 September 1897 en onder andere gesê: 'Is dit de wijse waarop gij, die tot mijne hulp in de Ned Herv Kerk van. de ZA Republiek zijt uitgezonden, uw plicht opvat? Terwijl ik meen (ook finantieel) waarlijk naar eer en plicht met $u$ te hebben gehandelt' (NHK 1898). Die woorde 'mij- ne hulp' was hout op die vuur! Spoelstra sou hierdie woorde kon aanvoer ter ondersteuning van sy saak dat Goddefroy hom slegs as 'n 'hulpprediker' beskou het.

Goddefroy het Spoelstra verder uitgenooi om arbitrasie in die saak in te roep. Ten slotte verklaar Goddefroy dat hy die saak in so 'n ernstige lig sien dat hy dit nie daar kan laat nie, maar dat hy dit voor die Kommissie van die Algemene Kerkvergadering sou lê. Daarmee het Goddefroy ongelukkig 'n stryd wat in der waarheid persoonlik van aard was en wat met die nodige takt plaaslik opgelos kon word, in die Kerk in breëre verband ingetrek. Dit sou nie net meer 'n botsing tussen Spoelstra en God-: defroy bly nie: Spoelstra sou teenoor die hele Nederduitsch Hervormde Kerk te staan kom!

Eintlik was dit maar 'n uiters geringe en onbelangrike saak wat die stryd laat ontbrand het. Ouderling A D W Wolmarans maak die korrekte uitspraak wanneer hy jare later die gebeure soos volg in herinnering roep: 'De oorzaken waren op zich zelf genomen niet van groot aanbelang, maar zooals het gewoonlijk gaat: kleine oorzaken hebben dikwels grote gevolgen. Zoo ook hier' (aangehaal deur Botha 1981:170). Die hele aangeleentheid bied egter genoegsame rede om 'n lank reeds bestaande spanning tussen Spoelstra en Goddefroy af te lei (Botha 1981:136). Die oorsaak van die stroewe verhouding tussen Spoelstra en Goddefroy word nêrens in die voorhande bronne eksplisiet gestel nie. Daar kan vermoed word dat die saak oor die $£ 10$ net maar die vonk was wat 'n sluimerende kruitvat laat vlam vat het.

Die geringe aard van die beginpunt van die botsing laat die vraag ontstaan of daar. nie dalk ander faktore was wat ' $n$ rol gespeel het in die aanvang van die botsing nie. Die eintlike oorsaak van die botsing is moeilik vasstelbaar uit die inligting wat beskikbaar is. Daar kan dus nou gespekuleer word oor moontlike bydraende faktore tot die genoemde beginpunt.

Die dood van Goddefroy se eggenote op 17 Mei 1896 (Botha 1981:97), kort voor Spoelstra se aankoms in Pretoria, kon 'n invloed gehad het op Goddefroy se gemoedstoestand wat weer sy interpersoonlike verhoudings kon beinvloed het. Dit blyk dat Goddefroy se eggenote 'n kalmerenede uitwerking gehad het op sy soms fluktuerende emosies. Pont (1980:44) stel dat dit vir Goddefroy 'n onherstelbare verlies was om die een wat die naaste aan hom geleef het en hom vir byna twintig jaar trou begestaan het, af te gee. Die feit dat hy nou in rou was en nie die ondersteuning van sy vrou gehad het nie, laat die vraag ontstaan of sy houding teenoor Spoelstra uit die staanspoor onberispelik was en of hy nie correageer het rondom die $\mathfrak{f 1 0} 10$-saak nie. 
Aan die ander kant lyk dit asof Spoelstra ook baie spanning moes verduur het wat weer op sy beurt ' $n$ invloed op sy interpersoonlike verhoudinge moes uitgeoefen het. Onder andere sterf sy oudste kind en naamgenoot, Cornelis Abraham, op 12 Junie 1896 (Spoelstra 1898:29). Daarby is sy vrou baie siek tydens haar swangerskap en sterf sy amper tydens die geboorte van hul dogtertjie, Carolina Antoinette Maria, op 3 Maart 1897 (Spoelstra 1898:30).

Hoe dit ookal sy, die botsing tussen Spoelstra en Goddefroy het 'n formele begin by die $£ 10$-saak. Op 19 September het Spoelstra, terwyl die $£ 10$-saak nog nie heeltemal afgehandel was nie, onverwags vanaf die kansel bekend gemaak dat hy op 1 Oktober 1897 die tuig as predikant in die Nederduitsch Hervormde Kerk sou neerlê.

\subsection{Die saak dien voor die kerkraad}

Op Maandag 11 Oktober 1897 het Spoelstra se aansoek om ontslag asook 'n aanklag van hom van 71 bladsye teen Goddefroy (Spoelstra 1898:iv) voor die kerkraadsvergadering van die gekombineerde Gemeentes Pretoria, Middelburg en Standerton gedien. Goddefroy het egter geweier dat daar oor die geskil tussen hom en Spoelstra op die kerkraadsvergadering gepraat word. Hy het aangevoer dat die saak op grond van Artikel 35 van hoofstuk VI van die Kerkwet by die Kommissie van die Algemene Kerkvergadering berus het. Die artikel het soos volg gelui: 'Geschillen in kerkeraadsver-gaderingen of tusschen kerkeraadsleden, zoo ook tusschen kerkeraden en leden der gemeente ontstaan, worden onmiddellijk gebracht voor de commissie der algem kerkverg en door haar beoordeeld' (aangehaal deur Botha 1981:170).

Daar kan beweer word dat Goddefroy op hierdie punt wel tegnies korrek was. Maar die vraag of dit 'n taktvolle reaksie op Spoelstra se griewe was, bly egter staan. Indien Goddefroy Spoelstra en sy griewe dalk met 'n oper gemoed benader het, sou die aangeleentheid dalk nie op 'n volskaalse botsing uitgeloop het nie. Maar daaroor kan daar bloot net gespekuleer word. Die kerkraad het nietemin tog besluit om aan Spoelstra inligting te gee op drie vrae wat hy aan die vergadering voorgelê het, naamlik:

(a) Wat ben ik hier? hulpprediker of tweede predikant van Pretoria?

(b) Heb ik het recht, als 2e predikant om te deelen in het Wed en Pensioenfonds voor dat deel der Gem dat door mij bearbeid wordt?

(c) Heb ik het recht, als ik de conculentsgem waarneem op de conculentsgelden? 
Goddefroy het Spoelstra op grond van die ingevoegde woorde, 'tot hulp van den tegenwoordigen staanden leeraar', in Spoelstra se beroepsbrief as sy 'hulpprediker' beskou (Engelbrecht 1953:353). Dié houding van Goddefroy het Spoelstra gegrief en daarom wou hy met sy eerste vraag uitsluitsel kry oor wat sy status in die gekombineerde gemeentes is. Ouderling C J Joubert het gesê die woorde 'tot hulp' is slegs in Spoelstra se beroepsbrief ingevoeg om te voorkom 'dat hier twee Ned Herv Gemeenten zouden ontstaan' (NHK kombinasie-gemeente 1897a). Derhalwe het die kerkraad geantwoord dat Spoelstra nie 'n hulpprediker was nie, maar tweede predikant van Pretoria. By hierdie kerkraadsvergadering was Goddefroy wel bereid om toe te gee dat Spoelstra die tweede predikant van Pretoria was, en nie slegs 'n hulpprediker nie.

Ten opsigte van die pensioenfonds het die kerkraad besluit om Spoelstra tegemoet te kom en, hoewel hulle nie daartoe verplig was nie, aan hom tog jaarliks 'n bedrag te betaal. Ten opsigte van die derde vraag is besluit dat Spoelstra nie verplig is om die konsulentsgemeentes te bedien nie. Wanneer hy dit tog wel doen, behoort die saak in verband met die konsulentsgelde met die konsulent van sodanige gemeentes gereël te word.

Spoelstra het daarop erken dat hy op sommige punte 'gedwaald hebben' en het sy beswaarskrif asook sy aanvraag om ontslag (dit wil sê sy bedanking) teruggetrek of herroep. Almal, ook Goddefroy, het hulle tevredenheid en blydskap met die verloop van sake uitgespreek. Skynbaar was die saak hiermee finaal opgelos en het die kerkraad begin om sake so te reël dat Spoelstra voortaan Standerton alleen sou bedien. Op hierdie stadium het Spoelstra die vergadering weens hoofpyn verlaat. Spoelstra het eers weer die middagsitting van die volgende dag, Dinsdag 12 Ok-tober, bygewoon. Tydens dié sitting het daar egter 'n onverwagte wending in die saak gekom. Goddefroy het die kerkraad versoek om ook drie vrae van sy kant af te beantwoord.

Ds Jac van Belkum, skriba van die Kommissie van die Algemene Kerkvergadering, het oor hierdie wending in die saak op 4 Maart 1898 aan Gildemeester berig dat hy dit as onbroederlik en onchristelik beskou 'dat iemand Maandag vrede maakt met zijn tegenpartij en Dinsdag d o v op nieuw het vuur aanblaast' (Van Belkum 1898b). Nog voordat die kerkraad hoegenaamd besluit het of daar ingegaan sou word op Goddefroy se versoek, het Spoelstra woedend geword en gedreig dat hy nie weer sou terugkeer tot die vergadering vóbr die Algemene Kerkvergadering hom nie as getuie roep nie. Met die woorde 'Ik zal mij niet langer als een kwajongen laten behandelen' het hy sonder toestemming die vergadering die rug gekeer (NHK kombinasie-gemeente 1897a). Goddefroy het egter kalm gebly. Hy het dit aan die vergadering gestel dat hy belaster is en dat hy gelyk gegee wou word.

Hoewel sommige kerkraadslede die nuwe stryd as vreemd, onnodig en skadelik beskryf het, is tog aan Goddefroy die geleentheid gegee om ook sy drie vrae aan die vergadering voor te lê: 
(a) Heb ik ooit of te immer in de Kerkeraad der Nederduitsch Hervormde Gemeente in Pretoria $c$ a begeerd, of er bepaald op aangedrongen dat een Hulpprediker moet worden beroepen?

(b) Is het met volle goedkeuring en medeweten van den Kerkeraad van Pretoria $\mathrm{c}$ a in den beroepsbrief naar Holland verzonden en door Ds Spoelstra ontvangen, de uitdrukking voorkomt "tot hulp van den tegenwoordigen staanden leeraar"?

(c) Hebben de Broeders Ouderlingen C J Joubert en G J Engelbrecht en N M Prinsloo die navolgende verklaring afgelegd voor Ds Spoelstra: “dan heeft Ds Goddefroy die woorden: tot hulp van de tegenwoordigen staanden leeraar er zelf tusschen geschreven, en wij hebben den beroefsbrief ter goeder trouw getekend"?

(NHK kombinasie-gemeente 1897a)

Die kerkraad (NHK kombinasie-gemeente 1897a) het Goddefroy se vrae so beantwoord:

(a) Goddefroy het wel by geleentheid "hulpprediker" voorgestel. Maar nadat die kerkraad Goddefroy daarop gewys het dat dit nie in belang van die kerk was nie, en dat hulle nie daarvoor te vinde was nie, het Goddefroy nie meer op 'n hulpprediker aangedring nie.

(b) Die betrokke woorde het wel in die beroepsbrief gestaan toe dit deur die kerkraadslede onderteken is.

(c) Die betrokke ouderlinge het nooit sodanige verklaring afgelê nie.

Dit is begryplik dat Goddefroy hom veronreg en beledig gevoel het deur Spoelstra se insinuasies dat hy met die beroepsbrief gepeuter het en dat van die kerkraadslede moontlik agter sy rug so 'n knoeiery bevestig het. Die vraag kan egter gevra word waarom Goddefroy, nadat die saak skynbaar tot almal se bevrediging afgehandel was, weer die saak opgehaal het. Verder is dit ook opvallend dat dit juis Goddefroy is wat opnuut die saak tussen hom en Spoelstra ophaal, want net die vorige dag het hy hom 
selfs op die kerkwet (artikel 35 hoofstuk VI) beroep toe hy geweier het dat die saak tussen hulle op die vergadering bespreek word. Botha beweer (1981:137) die blote feit dat Goddefroy die saak weer ophaal, is 'n bewys dat die probleem nooit werklik opgelos is nie.

Die verhouding tussen die twee predikante is in so 'n mate vertroebel dat 'n volgende botsing in elk geval onvermydelik was. Die geskil sou buitendien deur die Kommissie van die Algemene Kerkvergadering behandel moes word, aangesien Goddefroy dit reeds met 'n skrywe gedateer 5 Oktober 1897, dit wil sê vớr die kerkraadsvergadering, by Van Belkum van Rustenburg aanhangig gemaak het en gevra het om: '... zoo spoedig mogelijk eene vergadering saam te roepen van de Commissie der Alg Verg onser N H Kerk' (NHK 1898). Dit was waarskynlik juis met die oog op die behandeling van die saak deur die Kommissie dat Goddefroy op die betrokke vrae antwoorde van die kerkraad wou hê. Daarom het hy, nadat die kerkraad die vrae volgens hom bevredigend beantwoord het, gese dat hy die verklaring van die kerkraad nie sou gebruik om mee aan te val nie, maar om homself te verdedig.

Nieteenstaande die wending in die aangeleentheid, het die kerkraad tog besluit om die twis tussen die twee predikante te probeer bylê. Op voorstel van ouderling Botha (NHK kombinasie-gemeente 1897a) word 'n deputasie bestaande uit drie ouderlinge gekies om die twee predikante bymekaar uit te bring, sodat die saak tussen hulle geskik kon word. Die ouderlinge was broers Van Schalkwijk, Duvenhage en Wagner. Laasgenoemde was die skriba van die kerkraadsvergadering.

Intussen - tydens dieselfde middagsitting van Dinsdag 12 Oktober 1898 - het 'n brief by die kerkraad aangekom waarin Spoelstra die herroeping van sy aanvraag om ontslag (wat hy tydens die oggendsitting van Maandag 11 Oktober gedoen het) herroep het. Hierin het hy verklaar dat hy nou sy amp onherroeplik ('ditmaal onherroepelijk') neerlê. Voorts het hy 'n akte van ontslag en 'n getuigskrif vir goeie sedelike gedrag aangevra. Spoelstra het in dieselfde brief beweer dat hy op die kerkraadsvergadering (van dieselfde datum) deur Goddefroy skandalig behandel is (NHK1898). Die kerkraad het laasgenoemde as absoluut onwaar verwerp (NHK kombinasie-gemeente 1897a).

Op dieselfde dag het nog ' $n$ brief van Spoelstra die kerkraad bereik. Daarin stel hy die vergadering in kennis dat hy 'geen enkele Vergadering van uwen kerkeraad meer zal bijwonen, dat ik voor de Algm Commissie niet zal verschijnen ... en dat ik ook geen Godsdienstoefeningen meer zal houden in de Ned Herv kerk, waarmede ik voor goed gebroken heb'. Hy het hom egter bereid verklaar om skriftelik met die kerkraad in gesprek te tree (NHK 1898). 
$\mathrm{Na}$ die aanwys en uitstuur van ' $\mathrm{n}$ volgende deputasie bestaande uit ouderlinge De Lange en Visagie en nog verdere korrespondensie tussen die kerkraad en Spoelstra, en die kerkraad en Goddefroy (op 12 en 13 Oktober), het die kerkraad uiteindelik tog daarin geslaag om versoening tussen die twee predikante te bewerk (NHK kombinasiegemeente 1897a). Spoelstra het by die geleentheid verklaar: 'Mocht ik Ds Goddefroy ooit in iets beleedigd hebben, dan trek ik dat terug, vraag hem vergiffenis en wensch hem met zijn huis Gods besten zegen' terwyl Goddefroy aan Spoelstra gesê het: 'Als ik mocht misdaan hebben tegen u, vraag ik hartelijk om vergeving' (aangehaal deur Botha, 1981:138).

Die versoening het egter nie beteken dat Spoelstra afgesien het van sy voorneme om te bedank nie. Goddefroy het ook nie sy saak teen Spoelstra teruggetrek nie. Die kerkraad wou nie die akte van ontslag en getuigskrif vir goeie sedelike gedrag sonder toestemming van die Kommissie van die Algemene Kerkvergadering gee nie. Dit was nog hoegenaamd nie die einde van die botsing nie. Uiteindelik het dit daarop uitgeloop dat die hele saak voor die Algemene Kerkvergadering van 30 Maart 1898 gelê moes word.

\subsection{Verdere verwikkelinge wat die stryd kompliseer}

Nog voor die Algemene Kerkvergadering kon byeenkom, het verdere verwikkelinge plaasgevind wat die Spoelstra-Goddefroy-saak nog ingewikkelder gemaak het.

\subsection{Die Prokurasiekommissie-gemeente Pretoria raak betrokke}

Die Prokurasiekommissie-gemeente Pretoria was voormalige lidmate van die vroeëre Nederduitsch Hervormde Gemeente Pretoria wat in $\mathbf{1 8 8 5}$ met die kerkvereniging tussen die Nederduitsch Hervormde Kerk en die Nederduitsch Gereformeerde Kerk saamgegaan het, maar weer onder die Prokurasiekommissie wat in 1890 gevorm is, uitgetree het uit die Nederduitsch Hervormde of Gereformeerde Kerk ( $d$ i die Verenigde Kerk) en die Nederduitsch Hervormde Gemeente van Pretoria onder die konsulentskap van ds C W du Toit gevorm het (Botha 1981:171).

Die oprigting en optrede van die Prokurasiekommissie het tot gevolg gehad dat naas die Nederduitsch Hervormde Kerk met Goddefroy as predikant, wat histories en regmatig die voortsetting was van die ou staatskerk van die Zuid-Afrikaansche Republiek, ook nog 'n viertal Prokurasiekommissie-gemeentes, naamlik Potchefstroom, Pretoria, Wakkerstroom en Ventersdorp tot stand gekom het wat in 'n losse verhouding tot mekaar gestaan het. Vereniging of ineensmelting tussen die Nederduitsch Hervormde Kerk en die Prokurasiekommissie-gemeentes op sinodale vlak het sonder enige ernstige 
verskille of botsings verloop op 'n gekombineerde Algemene Kerkvergadering wat gehou is vanaf 30 April tot 4 Mei 1894 te Pretoria (Botha 1994:16).

In drie van die genoemde vier gemeentes het die eenheid ook op plaaslike vlak geen probleme opgelewer nie. In Pretoria het die ineensmelting egter vir byna tien jaar uitgebly te midde van allerlei spanninge en onenigheid. Aanvanklik is die vertraging rondom die afhandeling van die eiendomskwessie aangevoer as rede vir die uitstel om te verenig. Maar mettertyd het dit aan die lig gekom dat daar 'n dieperliggende oorsaak by die Prokurasiekommissie-gemeente was. Botha (1994:18-19) meen dat die gemeente om een of ander rede teensinnig was om Goddefroy as hulle predikant te aanvaar. Voorts het dit geblyk dat die stroewe verhoudinge tussen die twee gemeentes nou gekoppel was aan 'n stroewe verhouding tussen ouderling A D W Wolmarans en Goddefroy (Botha 1994:19).

Wolmarans het teen die einde van 1897 probeer om Spoelstra in die Prokurasiekommissie-gemeente beroep te kry (Botha 1981:138). Dit lyk asof dit moontlik kon wees dat Wolmarans in Spoelstra 'n bondgenoot teen Goddefroy gesien het. Die pogings van Wolmarans sou natuurlik dadelik die spanning tussen Goddefroy en Wolmarans aan die een kant, en die Nederduitsch Hervormde Gemeente Pretoria en die Prokurasiekommissie-gemeente Pretoria aan die ander kant laat toeneem en sodoende bydra tot 'n groter onwilligheid om met mekaar te verenig.

Op 'n gemeentevergadering van gemeente Pretoria op 15 Desember 1897 (NHK kombinasie-gemeente 1897b) het dit duidelik geword dat die Prokurasiekommissie-gemeente se betrokkenheid by die Spoelstra-saak deur Wolmarans se optrede baie vrae by gemeentelede laat ontstaan het en inderdaad die hele aangeleentheid verder gekompliseer het. Op hierdie vergadering is daar genoem van lyste wat in die gemeente gesirkuleer word ten gunste van Spoelstra om hom in die Prokurasiekommissie-gemeente beroep te kry.

\subsubsection{Optrede van Spoelstra}

Spoelstra het op 20 Januarie 1898 'n brief aan Van Belkum, die skriba van die Kommissie van die Algemene Kerkvergadering, geskryf waarin hy sy skrywe van 12 Oktober 1897 nou weer terugrek. In die skrywe van 12 Oktober 1897 het hy verklaar dat hy 'ditmaal onherroepelijk' sy amp neerlê. Dit het dus daarop neergekom dat hy op 12 Oktober sy bande met die Nederduitsch Hevormde Kerk verbreek het. Met die brief van 20 Januarie 1898 het hy nou weer die uitspraak herroep. Die vraag het nou ontstaan of hy nog langer predikant was of nie en of daar met die klag teen hom voortgegaan kon word of nie (Botha 1981:138). 


\subsection{Die saak dien voor die Algemene Kerkvergadering}

Die hele aangeleentheid rondom Spoelstra, tesame met die optrede van die Prokurasiekommissie-gemeente Pretoria en Spoelstra se brief van 20 Januarie 1898, het heelwat woelinge en onrustigheid in die Nederduitsch Hervormde Kerk tot gevolg gehad. Van Belkum en Du Toit het in hulle korrespondensie die vrees uitgespreek dat dit alles tot baie ernstige twiste en selfs skeurings in die Kerk kon lei (Botha 1981:171). Selfs in Nederland het die saak weerklank gevind, veral by die Commissie van Advies voor het uitzenden van Ned Herv Predikanten naar Transyaal. Dit was dié kommissie wat Spoelstra uitgestuur het en vir minstens twee jaar vir sy traktement verantwoordelik was. Die saak sou dus uiteraard juis by hierdie kommissie weerklank vind.

Die Algemene Kerkvergadering het op 30 Maart 1898 onder hierdie omstandighede byeengekom. Botha (1981:138 \& 171) meen dat Goddefroy gereed was vir die vergadering. Hy het geweet wat sy modus operandi moes wees. Hy was van plan om Spoelstra aan die kaak te stel as iemand wat wispelturig en onewewigtig was op wie nooit peil getrek kan word nie. Deur die loop van die vergadering het dit duidelik geword dat hy nie sulke bose voornemens gehad het soos wat Van Belkum aan hom toegedig het in 'n brief van 25 Februarie 1898 aan Du Toit nie: 'Ik kan niet anders dan dit inzicht in de zaak te hebben; de majestas (Ds Goddefroy) is geschonden, nu moet Spoelstra er uit .... Voorts moet A D W Wolmarans een knauw krijgen. Hij heeft voor Ds Spoelstra tegen Ds Goddefroy gewerkt ....' (Van Belkum 1898a).

Voor die vergadering het ' $n$ lang geskrewe stuk van Spoelstra gedien. Hy het daarin sy griewe teen Goddefroy uiteengesit, maar ook skerp aanvalle teen die Nederduitsch Hervormde Kerk geloods. Goddefroy het die geleentheid gekry om Spoelstra deeglik te antwoord op al die argumente en hy (Goddefroy) kon sy antwoord ook skriftelik (NHK 1898) voor die vergadering le. Die vergadering het dus hierdie twee stukke van die teenpartye in die stryd, plus al die korrespondensie in verband met die saak ter tafel gehad (NHK 1898). Daarby het die vergadering boonop besluit, veral op aandrang van Van Belkum, om Spoelstra ook persoonlik aan te hoor.

Uit die reeds genoemde skrywe van Van Belkum (1898a) aan Du Toit op 25 Februarie 1898 blyk dit dat Van Belkum groot simpatie met Spoelstra gehad het. Hy het nie Spoelstra se optrede goedgepraat nie, maar was tog van mening dat Spoelstra deur Goddefroy se manier van doen - 'ik wil doen wat ik wil en aan niemand rekenschap geven' (aangehaal deur Botha, 1981:171) - daartoe uitgelok is. Botha (1981:172) vra egter of Van Belkum se aanvanklike simpatie met Spoelstra nie grotendeels ontstaan het vanweë sy antipatie teen Goddefroy nie. Skynbaar was die verhouding tussen Van Belkum en Goddefroy nie altyd na wense nie en dit is waarskynlik daarom dat Van Belkum na Spoelstra persoonlik wou luister. 
Nadat die vergadering al die stukke en die getuienis sorgvuldig oorweeg het, is Goddefroy volkome gelyk gegee en is soos volg besluit:

De Vergadering, na gehoord te hebben de grieven van Ds Spoelstra en het verweerschrijft van Ds Goddefroy, neemt genoegen met de uiteenzetting van het verweerschrift, ingedien door Ds Goddefroy tegen de grieven van Ds Spoelstra en besluit beide stukken te publiceren.'

(NHK 1898)

Van Belkum het Spoelstra anders beoordeel nadat hy Spoelstra self kon ondervra. In die verklaring wat Van Belkum gedoen het, bestempel hy Spoelstra nie waardig om weer lidmaat van die Nederduitsch Hervormde Kerk te word nie, aangesien hy (Van Belkum) verlang '... dat voorgangers der Gemeente mannen van karakter ...' moet wees (NHK1898). Dit blyk dus uit die verklaring dat Van Belkum nou minder simpatiek teenoor Spoelstra staan, en daarmee eintlik vir Goddefroy in die saak gelyk gee. Uiteindelik het die hele stryd vir Goddefroy 'n groot oorwinning binne die Nederduitsch Hervormde Kerk geword. Die vergadering aanvaar eenparig en staande die volgende besluit:

De Vergadering, aan het einde van hare zittingen gekomen zijnde, heeft behoefte de Voorzitter ditmaal niet alleen dank te zeggen voor die wijze, waarop hij hare zittingen heeft geleid, maar in bijzonder wegens de trouw, waarmede hij voor de belangen der NHK in de ZAR heeft gewaakt; met de bede dat God hem nog lank spare en sterkte om onze Kerk te dienen en haar ten zegen voor onzen staat te doen zijn, gelijk zij dit van de vroegste tijden geweest is.

(NHK 1898)

Daarmee het die Spoelstra-episode amptelik tot 'n einde gekom in die Nederduitsch Hervormde Kerk. Deur Spoelstra se bedanking en deur sy verbreking van alle bande met die Hervormde Kerk het hy die pad afgesny om sy griewe deur die bevoegde regeervergaderings te laat behandel (Engelbrecht 1953:354). Daar kan nie beweer word dat Spoelstra alleen skuld gehad het nie, maar sy manier van optrede tydens sy bedanking en daarna was van so 'n aard dat hy diegene in die Nederduitsch Hervormde Kerk 
wat nog met hom gesimpatiseer het, soos byvoorbeeld Van Belkum, ook heeltemal van hom vervreem het. Voortaan beskuldig hy nie alleen Goddefroy nie, maar blameer hy die hele Nederduitsch Hervormde Kerk.

\section{SPOELSTRA VAL DIE NEDERDUITSCH HERVORMDE KERK AAN?}

\subsection{Van Zoeterwoude naar Pretoria}

$\mathrm{Na}$ die Algemene Kerkvergadering van 1898 was Spoelstra so bitter dat hy 'n boekie genaamd Van Zoeterwoude (sy eerste gemeente in Nederland) naar Pretoria (sy eerste en laaste gemeente in Nederduitsch Hervormde Kerk) met die subtitel Brieven aan de leden van den Ring Alfen aan den Rijn over mijn uittreden uit de "Nederlandsch Hervormde Kerk" in de ZAR publiseer. In die boekie sit hy sy kant van die GoddefroySpoelstra-saak uiteen. Op die voorblad laat hy die volgende aanhaling uit Satan's Invisible World Displayed van W Stead druk:

It is the old, old story. As long as you sit still and say nothing, you are all right, but the moment you call attention to a hideous wrong or a shameful crime, all those whose iniquities you have disclosed combine with your enemies in order to make a busy Public believe that it is you who have exposed the crime who is the real criminal, while they, poor innocents, are the injured parties, for whom a respectable Public should have nothing but sympathy and consideration.

(Spoelstra 1898)

Hieruit kan die afleiding gemaak word dat Spoelstra homself van alle blaam in die saak met Goddefroy en die kerkraad van die Gemeente Pretoria onthef. Hy stel homself teenoor die Nederduitsch Hervormde Kerk as die een wat al die onreg en kwaad in die Kerk uitgewys het. Dit blyk uit sy boekie dat hy nie op 'n objektiewe wyse die saak beskryf nie, maar op 'n subjektiewe wyse homself - die veronregte - in 'n gunstige lig probeer stel. Die boek ontaard in 'n heftige aanval op die hele Nederduitsch Hervormde Kerk op grond van 'n behandeling wat hy van een persoon ondervind het. Spoelstra (1898:107) maak die uitspraak 'de "Hervormde" Kerk heeft geen zegen gebracht over de Zuid-Afrikaansche Republiek’.

In sy slotwoord verklaar hy dat hy en die Ring van Alfen, aan wie hy die boekie in die besonder rig, 'n strategie moet uitwerk om, met behulp van Van Zoeterwoude naar Pretoria: te bewerken: 
(a) Dat de Synode der Ned ('Nederlandse') Herv Kerk openlijk uitspreke dat zij in geenerlei verhouding staat tot de gelijknamige kerk in Transvaal;

(b) Dat de Synode tevens openlijk zal gelieven te waarschuwen tegen het overgaan harer predikanten naar de zich ten onrechte noemende "Ned Herv Kerk in de ZAR".

(c) Dat broeders Leeraren alle attestatties; die voor Transvaal opgevraagd worden, zullen gelieven te adresseeren aan Kerkeraad der Ned Herv of Ger Kerk te Pretoria (p/a Ds H S Bosman) waar zij rechtens thuis behooren en

(d) Dat broeders en zusters in Nederland geen financiëele hulp meer zullen verleenen aan een "kerk" die daarop recht noch aanspraak heeft.

(Spoelstra 1898:116)

Engelbrecht (1955:94) beweer dat die boekie van so 'n aard was dat dit nie die effek waarop Spoelstra gehoop het, gehad het nie. Van Belkum het in die tydskrif van dr A W Bronsveld, Stemmen voor Waarheid en Vrede, in 1898 'n afdoende antwoord op dié sensasiewekkende boekie van Spoelstra (Engelbrecht 1929:155) onder die opskrif 'De Ned Hervormde Kerk in Zuid-Afrika' gepubliseer (Engelbrecht 1953:354). Die uitwerking van die boekie op die Nederduitsch Hervormde Kerk en op die verhouding tussen Spoelstra en dié Kerk was net soos wat Van Belkum in sy genoemde artikel aan Spoelstra geskryf het:

Uw boekje zal de Ned Herv Kerk van Afrika geen kwaad doen. Al wie nog eenige sympathie voor $u$ had, zal die voelen verflauen, want gij hebt aangetast de Kerk. En hoe vol gebreken de Afrikaners in de Z Afrika's Republiek mogen zijn: hun Kerk hebben ze lief en hun Kerk te laten schelden dat dulden ze niet.

(aangehaal deur Engelbrecht, 1953:354)

Volgens Engelbrecht (1955:94) is Van Zoeterwoude naar Pretoria wel deur ds H S Bosman, predikant van die Nederduitsch Hervormde of Gereformeerde Kerk Gemeente 
Pretoria, aangegryp. In De Vereeniging, die amptelike blad van die Nederduitsch Hervormde of Gereformeerde Kerk is met groot ophef uittreksels daaruit gepubliseer en is Spoelstra as 'n soort held beskou. Engelbrecht (1953:354) stel ook dat die boekie in die genoemde blad 'n 'verstandig woord' en 'een onpartijdig oordeel' genoem word wat aanbeveel is om gelees en herlees te word.

\section{2 'n Artikel in de Nederlandsche Kerkbode}

In 1903 tydens 'n besoek van ouderling A D W Wolmarans aan Nederland om 'n predikant vir die Prokurasiekommissie-gemeente Pretoria te soek, neem Spoelstra die pen op in de Nederlandsche Kerkbode van 10 en 31 Oktober om die Nederlandse Hervormde predikante te waarsku om nie beroepe na die Nederduitsch Hervormde Kerk in Transvaal aan te neem nie (Engelbrecht 1953:355).

Hierdie aanslag van Spoelstra teen die Nederduitsch Hervormde Kerk het egter niks uitgerig nie. Wolmarans staan hom op meesterlike wyse in die genoemde Kerkbode te woord in die uitgawes van 17 Oktober en 7 November 1903. Ook het J E N Baron Schimmelpenninck van de Oye van Hoevelaken, dr F van Gheel Gildemeester en dr J Th de Visser in die uitgawe van 17 Oktober, en G A A Middelberg, J A van Kretschmar van Veen en dr N Mansvelt in die uitgawe van 24 Oktober die pen teen Spoelstra ten gunste van die Nederduitsch Hervormde Kerk opgeneem. Wolmarans slaag derhalwe wel daarin om prof P J Muller te vind om die beroep na Pretoria aan te neem (Engelbrecht 1929:155).

\subsection{Bouwstoffen voor de geschiedenis der Nederduitsch-Gereformeerde Kerken in Zuid-Afrika}

Hierdie boek word in 1906 en 1907 in twee lywige volumes deur HAUM in Amsterdam uitgegee. Spoelstra maak volgens Smit (1981:632) hiermee wel 'n waardevolle bydrae tot kerkgeskiedskrywing aangesien hy sommige primêre bronne vir die eerste keer in gedrukte vorm uitgee. Die vraag bly egter of die samestelling van bronne vir die geskiedenis van die Nederduitsch Gereformeerde Kerk nie vir Spoelstra 'n subjektiewe aangeleentheid was nie. Hy wend hom na die Nederduitsch Gereformeerde Kerk in reaksie op die Nederduitsch Hervormde Kerk. Wanneer sy ander geskrifte, wat volgens hom veronderstel is om wetenskaplik-histories te wees maar wat na 'n nadere ondersoek geskiedskrywing vanuit 'n subjektiewe invalshoek blyk te wees, in ag geneem word, kan dit betwyfel word of hy dan juis in hierdie twee volumes van werkswyse sou verander. Die moontlikheid bestaaan dus dat Spoelstra deur middel van 'n selektiewe aanbieding van bronne 'n bedekte hou na die Nederduitsch Hervormde Kerk gemik het. 


\subsection{Het Kerkelijk en Godsdienstig leven der Boeren na den Grooten Trek: His-} torisch Kritisch Onderzocht

Ter inleiding word daar eers gekyk na die omstandighede waartydens Spoelstra die lywige boek geskryf het: Toe professor Muller in 1909 na Nederland terugkeer, was Spoelstra sonder 'n standplaas in Nederland en kon hy ook nie daarin slaag om 'n beroep in die Nederduitsch Hervormde of Gereformeerde Kerk te kry nie. Engelbrecht (1929:156) maak die afleiding dat broodgebrek Spoelstra in die oë gestaar het. Ten einde raad probeer hy dan om weer in die Nederduitsch Hervormde Kerk Gemeente Pretoria beroep te word. Indien hulle hom nie beroep nie vra hy dat die kerkraad vir hom as voorspraak sal optree, sodat hy na 'n ander gemeente in die Nederduitsch Hervormde Kerk beroep kan word.

Op 9 Junie 1910 skryf hy 'n brief aan die kerkraad van gemeente Pretoria waarin hy onder andere bogenoemde versoeke rig. Spoelstra (1911:4) verklaar verder in die brief dat hy in 'n skrywe aan Wolmarans, gedateer 2 Julie 1909, sy briewe in de Nederlandsche Kerkbode en sy boekie Van Zoterwoude naar Pretoria heeltemal en onvoorwaardelik herroep het: Ik herroep derhalve al dat geschrijf onvoorwaardelijk en zonder terughouden (dit is Spoelstra se kursivering). Hy versoek voorts dat dié herroeping as Apologie aan de geheele Nederduitsch Hervormde Kerk in Zuid Afrika (weer eens Spoelstra se kursivering) '... publiek bekend worde door dezen brief te doen plaatsen in de Hervormer ...'(Spoelstra 1911:4). Hy betreur die breuk met die Nederduitsch Hervormde Kerk en vra dat 'n broederhand opnuut na hom uitgereik moet word (Engelbrecht 1942:49).

Die kerkraad van die Gemeente Pretoria het nie aan sy versoek vir 'n beroep voldoen nie, omdat dit vir hulle duidelik was dat broodgebrek hom tot die apologie gedryf het (Engelbrecht 1929:156). Uit Spoelstra se verdere optrede in 1912 met sy terugkeer na Transvaal het dit geblyk dat sy apologie nie opreg bedoel was nie. Hy kom na Transvaal met die hoop dat die Nederduitsch Hervormde of Gereformeerde Kerk hom sou beroep. In Potchefstroom het hy 'n aantal lesings oor die Transvaalse kerkgeskiedenis aangebied wat prof S P Engelbrecht bygewoon het (Engelbrecht 1929:156). Dit het egter halfpad doodgeloop aangesien die gehoor as gevolg van die 'hatelikheid" teen die Nederduitsch Hervormde Kerk belangstelling verloor het (Engelbrecht 1929: 156).

Engelbrecht (1929:156) beweer dat die gedrukte program van bogenoemde lesings byna soos die inhoudsopgawe van 'n baie dik boek (van ongeveer 600 bladsye) gelyk het. Wanneer Het Kerkelijk en Godsdienstig leven der Boeren na den Grooten trek: Hisorisch Kritisch Onderzocht in 1917 verskyn, is dit inderdaad 'n lywige geskrif met selfs meer as 600 bladsye. Dit wil dus lyk asof Spoelstra reeds hard besig moes gewees 
het aan die skryf van hierdie boek toe hy in 1909 en 1910 sy apologie aan die Nederduitsch Hervormde Kerk gerig het. Terwyl hy besig was met 'n boek waarin hy die Nederduitsch Hervormde Kerk aanval en waarin hy 'n vertekende beeld van die Hervormde Kerk gee, probeer hy terseldertyd witvoetjie soek by die Kerk. Voorwaar 'n eienaardige situasie - indien genoemde afleiding korrek is.

In Het Kerkelijk en Godsdiestig leven het Spoelstra probeer om die histories-gemotiveerde aanvalle wat ds F Lion Cachet, aan wie die boek opgedra is (Spoelstra 1915/ 1917), in die sestiger jare en ds N L Neethling in die tagtiger jare van die negentiende eeu op die Nederduitsch Hervormde Kerk gemaak het, wetenskaplik te motiveer. Dit doen hy deur die historiese bronne baie selektief te gebruik en alles te ignoreer wat nie pas in die historiese beeld wat hy wou skep nie. Hierdie werkswyse kan nouliks deurgaan vir wetenskaplikheid waar ' $n$ redelike mate van objektiwiteit ' $n$ vereiste is.

Kerkhistorici van binne en van buite die Nederduitsch Hervormde Kerk beskou hierdie boek van Spoelstra beswaarlik as betroubare historiese materiaal. Engelbrecht (1953:355), van binne die Nederduitsch Hervormde Kerk, sit die historiese onbetroubaarheid van die boek uiteen in 'n artikel getiteld Een Histories-Krities Onderzoek Histories-Krities Onderzocht wat in 1917 in Stemmen voor Waarheid en Vrede verskyn. In 'n reeks artikels Ds Spoelstra en de Hervormde Kerk in De Hervormer van 4 Maart tot 23 April 1929 wy Engelbrecht uit op die historiese onbetroubaarheid en onjuisdhede in die boek. Hy toon aan dat die boek eintlik eerder propaganda as kerkgeskiedenis is. 'n Deurlopende polemiek teen die Nederduitsch Hervormde Kerk word bespeur. Engelbrecht (1929) noem dit 'een gescheld van de grofste soort'. Ook Van Belkum het op Het Kerkelijk en Godsdienstig leven in de Hervormer van 1917 gereageer. Volgens Smit (1981:632), van buite die Nederduitsch Hervormde Kerk, bevat dit wel waardevolle historiese materiaal, maar vir wetenskaplike geskiedskrywing kan dit nouliks deurgaan.

\section{GEVOLGTREKKING}

Die Spoelstra-episode is in die Nederduitsch Hervormde Kerk in die verlede dikwels verswyg. As rede kan aangevoer word dat die Hervormde Kerk nie graag aan hierdie ongelukkige gebeurtenis herinner wil word nie. Dit was in 1996 eenhonderd jaar gelede gewees nadat Spoelstra predikant geword het in die Nederduitsch Hervormde Kerk, Gemeente Pretoria. Dit blyk dus 'n gulde geleentheid te wees om in die lig daarvan, en ook terwyl dit die 140e bestaansjaar van Gemeente Pretoria is, Spoelstra en die gebeure rondom hom in oënskou te neem. 
Wanneer die Spoelstra-episode in hierdie artikel onder die soeklig geplaas word, is die vertrekpunt die vraag na die die verhouding tussen Spoelstra en die Nederduitsch Hervormde Kerk. In hierdie verhouding staan die botsing tussen Spoelstra en Goddefroy voorop. Hierdie eienaardige kontrovers was bepalend vir die aard van die verhouding tot aan die einde van Spoelstra se lewe.

Dit blyk uit die studie dat dit inderdaad 'n eienaardige kontrovers was. Dit bly 'n vraag of die oorsaak van die botsing ooit werklik bepaal sal kan word. Die oorsaak wat wel gegee word, blyk te gering te wees om so 'n botsing tot gevolg te hê. Dit wil dus lyk asof daar ander faktore was wat ' $n$ rol in die botsing moes gespeel het. Hieroor kan daar net gespekuleer word. Hoe dit ook al sy, Spoelstra het te midde van groot onenigheid die Kerk verlaat. 'n Mens sou verwag dat die saak met sy bedanking afgehandel is. Vir Spoelstra was dit egter nie die geval nie. Sy verdere optrede toon dat hy verbitterd teenoor die hele Kerk gestaan het.

Dit kan betreur word dat 'n persoonlike vete tussen twee ampsdraers uitgekring het tot 'n stryd gemik teen die hele Kerk. Spoelstra het na sy bedanking uit die Nederduitsch Hervormde Kerk voortgegaan om aanvalle teen die Kerk te loods. Selfs in sy geskiedkundige werke blyk dit dat hy die kerk nie goedgesind was nie. Die afleiding kan gemaak word dat Spoelstra se geskrifte eerder 'propaganda' as geskiedenis is. Hy gee ' $n$ vertekende, halwe beeld van die waarheid en derhalwe is dit waardeloos. Die werkmetode van Spoelstra en die resultate wat daarmee verkry word, het heelwat navolging gevind, sodat selfs gepraat kan word van kerkhistorici van die Spoelstra-skool (Botha 1981:139) Spoelstra se eensydige interpretasie van die geskiedenis was inderdaad bruikbaar vir mense wat aksies teen die Nederduitsch Hervormde Kerk wou rig. Hoewel hierdie soort geskiedskrywing gewoonlik die doel voor oë het om die Nederduitsch Hervormde Kerk af te maak en hom van sy bestaansreg te ontsê, het dit andersyds die voordeel dat die Nederduitsch Hervormde Kerk en sy ampsdraers hulle terdeë op hoogte van die geskiedenis van die Kerk moet hou.

Weens Spoelstra se botsing met Goddefroy en sy (Spoelstra se) aanvalle op die Kerk, word dit maklik uit die oog verloor dat hy, soos Smit (1981:632) en Engelbrecht (1953:356) dit stel, 'n begaafde prediker en 'n toegewyde navorser (Smit:632) was. Indien die botsing nooit plaasgevind het nie, sou hierdie eienskappe van Spoelstra heel mootlik tot voordeel van die Nederduitsch Hervormde Kerk aangewend kon word.

\section{Literatuurverwysings}

Botha, S J 1981. Ds Marie Joseph Goddefroy 1848-1920: Sy lewe en betekenis. Pretoria: HAUM. 
Botha, S J 1994. Die 'vereniging' van die gemeentes onder leiding van die Prokurasiekommissie met die Nederduitsch Hervormde Kerk in 1894. Ongepubliseerde lesing gehou voor die Kerkhistoriese Genootskap in Pretoria.

Engelbrecht, S P 1929. Ds Spoelstra en de Hervormde Kerk. De Hervormer 20/10, bl 155-157.

- 1929. Ds Spoelstra en de Hervormde Kerk. De Hervormer 20/11, bl 167.

- 1929. Ds Spoelstra en de Hervormde Kerk. De Hervormer 20/14, bl 202-203.

- 1929. Ds Spoelstra en de Hervormde Kerk. De Hervormer 20/15, bl 216-217.

— 1929. Ds Spoelstra en de Hervormde Kerk. De Hervormer 20/16, bl 223-225.

- 1929. Ds Spoelstra en de Hervormde Kerk. De Herwormer 20/17, bl 238-242.

1942. Eeufees-album, Nederduitsch Herwormde Kerk 1842-1942. Pretoria.

- 1953. Geskiedenis van die Nederduitsch Hervormde Kerk van Afrika. 3de uitgawe. Pretoria/Kaapstad: HAUM/J H de Bussy.

- 1955. Die Nederduitsch Hervormde Gemeente Pretoria 1855-1955. Pretoria.

Nederduitsch Hervormde Kerk. Algemene Kerkvergadering 1898. Notule van die Algemene Kerkvergadering: Die Spoelstra-saak 1898. K1/1 3/3/14. Argief van die Nederduitsch Hervormde Kerk, Pretoria.

Nederduitsch Hervormde Kerk kombinasie-gemeente Pretoria-Middelburg-Standerton 1897a. Gekombineerde Kerkraadsvergadering 1897. Notule van die Gekombineerde Kerkraadsvergadering 11-17 Oktober 1897. G4 1/2/2. Argief van die Nederduitsch Hervormde Kerk, Pretoria.

1897b. Gemeentevergadering Gemeente Pretoria 1897. Notule van Gemeentevergadering 15 Des 1897. G4 1/2/2. Argief van die Nederduitsch Hervormde Kerk, Pretoria.

Pont, A D 1978. Kerkgeskiedenis. Pretoria/Kaapstad: HAUM.

- (red) 1980. Die Nederduitsch Hervormde Gemeente Pretoria 1855-1980. Enkele grepe uit die geskiedenis. Pretoria.

Pont, A D, Botha S J, \& Storm, J M G 1986. Gedenkalbum 1886-1986. Pretoria: NHW-Pers.

Smit, A P 1981. S v Spoelstra C, in Beyers, C J (red), Suid-Afrikaanse Biografiese Woordeboek, Deel IV, 631-632. Durban: Butterworth \& Kie.

Spoelstra, C 1898. Van Zoeterwoude naar Pretoria. Kaapstad: Jacques Dusseau.

- 1911. Apologie aan Pretoria gemeente en aan de geheele Nederduitsch Hervormde Kerk in Zuid-Afrika. De Hervormer 2/22, bl 4.

1915 (1917). Het Kerkelijk en Godsdienstig leven der Boeren na den Grooten Trek: Historisch kritisch onderzocht. Kampen: J H Kok. 
Van Belkum, J 1898a. Brief aan ds C W du Toit, 25 Feb 1898. L VI 1/2. Argief van die Nederduitsch Hervormde Kerk, Pretoria.

1898b. Brief aan dr F van Gheel Gildemeester, 4 Mrt 1898. L VI 1/2d. Argief van die Nederduitsch Hervormde Kerk, Pretoria. 